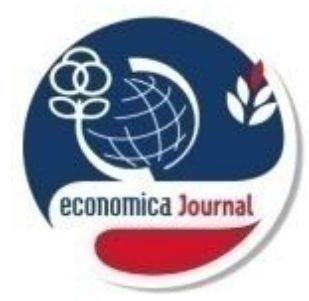

ISSN : $2302-1590$

E-ISSN: $2460-190 X$

\title{
ECONOMICA
}

Jurnal Program Studi Pendidikan Ekonomi

STKIP PGRI Sumatera Barat Vol.8 No.1 (46-50)

\section{ANALYSIS OF FACTORS AFFECTING CAPITAL STRUCTURE / LEVERAGE OF WASKITA KARYA}

\author{
By \\ Hutomo Adhi ${ }^{1)}$, Mohamad Fany Alfarisi ${ }^{2)}$ \\ ${ }^{1)}$ Faculty of Economics, Andalas University \\ Email: hutomo.adhi93@gmail.com \\ ${ }^{2)}$ Faculty of Economics, Andalas University \\ Email: mfany@eb.unand.ac.id \\ Submited: 2019.09.19 Reviewed: 2019.09.20 Accepted:2019.10.30 \\ https://doi.org/10.22202/economica.2019.v8.i1.3605
}

\begin{abstract}
The purpose of this study was to analyze effects of profitability, Fixed Asset Ratio (FAR), Exchange Rate Risk (ExRisk) and growth on the capital structure / leverage of state-owned enterprises (SOE). This research was conducted at 7 state-owned construction enterprises in Indonesia. The results of this study indicated a positive and significant influence between profitability on the leverage of SOE Karya companies. The existence of a negative and significant influence betw could een Fix Asset Ratio on the leverage of SOE Karya. There was a positive influence between the variables growth and leverage but the statistical value was not significant. Exchange rate risk has a positive but not significant effect on leverage.
\end{abstract}

Jel Classification:

D25; E22

Keywords: profitability, Fix Asset Ratio, growth, Exchange rate risk . leverage 


\section{INTRODUCTION}

Now, capital structure was increasingly important associated with determining optimal combination of investment needs that could increase the value of the company. Corporate capital structures behavior in Indonesia was quite unique because it was a new market, with the largest national economy in the Southeast Asian region (Baker \& Powell, 2012 in Haron, 2016). Central Statistics Agency noted that Indonesia's economic growth in 2018 reached $5.17 \%$. Construction sector ranks third as a driver of economic growth in 2018. Nowadays, government was carried out infrastructure development through priority project policies and national strategic programs, most of them involve state-owned companies in their implementation. From 2014 to 2019 administration period, there were about 227 international strategic project plans (Presidential Regulation Number 56 of 2018), and 37 projects with priority categories (Source: kppip.go.id). This infrastructure projects would increase the company's activities, due to an increase of assets, liabilities, and equity. There were many determinants of target capital structure (optimal), including profitability, Fixed Asset Ratio (FAR), Exchange Rate Risk (ExRisk) and growth. This study aimed to analyze effect of profitability, FAR, ExRisk and growth on capital structure / leverage of state-owned enterprises (SOE).

\section{METHODS}

This research was conducted using a quantitative approach. This research was conducted at 7 state-owned construction enterprises in Indonesia: PT. Waskita Karya (Tbk), PT Wijaya Karya (Tbk), PT. Adhi Karya (Tbk), PT. PP (Tbk), PT Hutama Karya (Persero), PT Brantas Abipraya (Persero) and PT Nindya Karya (Persero). variables studied in this study are profitability, Fixed Asset Ratio (FAR), Exchange Rate Risk (ExRisk), growth and leverage. Data used in this study are secondary data. Collection and analysis of 49 company time series data was conducted from financial reports published annually through the company's official website in the period 2011-2017. A panel data regression was conducted to statistical test using Eviews 8 
Table 1. Variable Calculation Method

\begin{tabular}{cc}
\hline Variable & Calculation \\
\hline Profitability & EBIT/ Total Assets \\
Fixed Asset Ratio (FAR) & Fixed Assets/ Total Assets \\
Growth & $\frac{\text { Sales }_{t}-\text { Sales }_{t-1}}{\text { Sales } s_{t-1}}$ \\
Exchange Rate Risk (ExRisk) & Percentage Change in Currency Exchange \\
& Rates $=\frac{s-S_{t-1}}{S_{t-1}} \times 100 \%$ \\
Leverage & Total liabilities/Total assets \\
\hline
\end{tabular}

\section{RESULTS AND DISCUSSION}

Table 2 presented results of descriptive statistics of data that has been conducted, while results of panel data regression analysis are shown in Table 3.

Table 2. Descriptive Statistics

\begin{tabular}{cccccc}
\hline Statistik & Leverage & Profitability & $\begin{array}{c}\text { Fixed Asset Ratio } \\
\text { (FAR) }\end{array}$ & Growth & $\begin{array}{c}\text { Exchange Rate } \\
\text { Risk (ExRisk) }\end{array}$ \\
\hline Mean & 0.756 & 0.057 & 0.087 & 0.297 & 0.058 \\
Median & 0.760 & 0.057 & 0.066 & 0.261 & 0.021 \\
Maks. & 0.879 & 0.150 & 0.289 & 1.121 & 0.248 \\
Min. & 0.487 & 0.015 & 0.010 & -0.121 & -0.036 \\
SD & 0.079 & 0.028 & 0.064 & 0.266 & 0.093 \\
\hline
\end{tabular}

Table 3. Results of panel data regression test

\begin{tabular}{ccccc}
\hline Variable & Coefficient & $\begin{array}{c}\text { Standar } \\
\text { Error }\end{array}$ & t & $\boldsymbol{p}$ \\
\hline Profitability & 0.795 & 0.430 & 1.849 & $0.072^{*}$ \\
Fixed Asset Ratio (FAR) & -0.619 & 0.244 & -2.540 & $0.015^{*}$ \\
Growth & 0.018 & 0.049 & 0.376 & 0.708 \\
Exchange Rate Risk (ExRisk) & 0.026 & 0.119 & 0.218 & 0.828 \\
\hline \multicolumn{2}{c}{$\mathrm{R}^{2}$} & & \multicolumn{3}{c}{0.22} \\
\hline
\end{tabular}

\section{* Significant}

Table 3 showed positive and significant influence between profitability on leverage of SOE Karya. Existence of this positive and significant influenced indicates that greater value of profitability, greater value of SOE Karya's leverage. Lower value of profitability, lower leverage value of SOE Karya.

Brigham \& Houston (2013) explained that companies with very high return on investment actually often use relatively small amounts of debt. However, there was no theoretical justification for this fact. One 
practical explanation was that a very profitable company does not need too much debt funding. High rate of return allowed company to use most of its funding from internal sources.

Table 3 also showed that there was a negative and significant influence between Fix Asset Ratio (FAR) to leverage of SOE Karya. This negative and significant influenced indicates that greater of FAR, smaller leverage of SOE Karya. Lower FAR, greater leverage of SOE Karya.

This mean that an increase in company's fixed assets could make a productive contribution to company so that it could significantly give opposite effect on leverage decisions. It was suspected that company's fixed assets are not always used as collateral by company's management to make additional debt. Credibility of the government as a shareholder, implementation of good corporate governance (GCG), improvement of company's image through corporate social responsibility (CSR) programs was enough to determine ability of company management to get loans or increase amount of debt and make leverage decisions. In addition, it was important for management to always maintain optimal leverage levels and prevent financial distress.

Findings in this study were in accordance with the publications of Sheikh \& Wang (2011), Alzomaia (2014), Li \& Stathis (2017). However, Bunkanwanicha (2008), De Jong (2008), Moosa \& Li (2012) as quoted by Haron (2016) found that tangibility or fixed assets ratio and leverage had positive and significant correlations.

Table 3 also showed growth has a coefficient of 0.018682 with a significance value of 0.7083 ( $p>0.1$ ). So, even though polarity of regression coefficient stated that there was a positive influence between growth and leverage variables, the statistical value was not significant.
According to Bigham \& Houston (2013), if cateris paribus, companies with faster growth tend to rely on use of external funds (debt). However, at same time, company often faced higher uncertainty (risk) that encourages companies to reduce use of debt.

In Table 3, it was known that exchange rate has a coefficient of 0.026144 with a significance value of $0.8284(p>0.1)$. So that exchange rate variable has a positive and not significant fall in leverage. This finding supported results of Panda \& Nanda's (2015) study which states that companies could be exposed negatively or positively to exchange rate risk. An increase in the amount of debt could result in a company being more likely to be exposed to exchange rate risk. These results proved need for a hedging strategy (hedging) to be operated in company operations.

\section{CONCLUSION}

There was a positive and significant effect between profitability on leverage of SOE Karya. There was a negative and significant influence between FAR on leverage of SOE Karya companies. There was a positive influence between growth and leverage but the statistical value was not significant. Exchange rates had a positive and not significant effect on leverage.

\section{REFFERENCE}

Alzomaia. 2014. Capital Structure Determinant of Publicy Listed Companies in Saudi Arabia. The International Journal of Business and Finance Research, 8(2), 53-67.

Brigham \& Houston. 2013. Essential of Financial Management (terjemahan), Buku 2 (edisi 11), Jakarta: Salemba Empat.

Haron (2016), “Do Indonesian Firm Practice Target Capital Structure ? A dynamic 
Approach". Journal of Asia Business Studies, 10(3), 318-334.

Li \& Stathis. 2017. Determinants of Capital Structure in Australia: An Analysis of Important Factors. Managerial Finance, 43(8), 881-897.

Panda, A.K. \& Nanda, S. 2015. Capital Structure and Exchange Rate Risk: An Emperical Analysis of India NonFinancial Firm, Udyog Pragati, 39(3), July-September.

Sheikh \& Wang. 2011. Determinant of Capital Structure: An Emperical Study of Firms in Manufacturing Industryof Pakistan, Managerial Finance, 37(2), 117-133. 